\title{
BOARD DIVERSITY ON FIRM VALUE OF FINANCIAL INSTITUTIONS
}

\author{
Doka Lenge Shaki ${ }^{1}$, Victor Falack ${ }^{1}$, Adiga Maurice ${ }^{1}$ and Bassey, Emmanuel U. ${ }^{2}$ \\ ${ }^{1}$ Department of Accountancy, Taraba State University, Jalingo. \\ ${ }^{2}$ School of Basic Studies, Taraba State University, Jalingo. \\ Email: emmanueludebassey@gmail.com
}

\begin{abstract}
The study examined the effect of board diversity on firm value of financial institutions in Nigeria. This study focused on deposit money banks (DMBs), the 14 listed deposit money banks were studied using expost facto with data sourced from NSE annual financial reports from 2010-2019. The predictors gender diversity, educational qualification and independent directors showed a linear effect on firm value. Gender diversity measured as the ratio of female on board of directors showed a positive effect on firm value. The different academic qualifications of directors ranging from Ph.D., M.Sc. and B.Sc. showed a negative effect on firm value. Independent directors measured as the ratio of non-executive directors on the board showed a positive effect on firm value.
\end{abstract}

Keywords: Board diversity, Gender diversity, Non-executive director, Firm value, Market price per share. 


\section{Introduction}

Diversity is the variation of social and cultural identities among people existing together in a defined employment or market setting. Social and cultural identity refers to the personal affiliation with groups that research has shown to have significant influence on peoples' major life experiences. These affiliations include gender, race, national origin, religion, age cohort and work specialization, among others (Cox, 1991; Marumuthu, 2008).

Board diversity is a contemporary issue in corporate governance, the issue of diverse demographics and cognitive diversity as represented in the board has gained international concern and research focus (Erhardt, Werbel \& Shrader, 2003). Board structure is one of the key elements for the effectiveness of board functions. The diversity of knowledge, qualifications and experience of directors (e.g., human capital) in boardroom enhance the boards' decision-making processes (Hillman 2015; Campbell \& Minguez-Vera 2008).

Board diversity especially with relation to demographicsvaries from country to country, indicating that the approach of one country might not be applicable to other countries. Evidence from previous submissions shows mix findings. A meta-analysis study in 2014 posits that board diversity should be broad covering gender, race/ethnicity, age and nationality.

Board diversity should be widely considered covering several perspectives not over sighting skills, experience, expertise, ethnicity, age, nationality and other demographics.

The necessity of board diversity on corporate entities cannot be overemphasized, as it gives room to idea and experience diversity as well as creating a board circle of diverse professionalism and personalities. The theoretical and empirical complexity of board diversity concept has spurred up research interest on its impact on accounting performance and market performance in countries and industries.

The study enlarges on board diversity by considering gender, educational qualification and independent director's diversity and firm value of financial institutions in Nigeria.

\section{Gender Diversity}

Gender diversity is viewed as equitable or fair representation of personalities of different genders in a corporate board. In contemporary situations, it might include people of non-binary genders. In assumption, fair representation of women as directors or board members will tend to benefit management and further increase returns. This assertion is debated as previous researches show conflicting results regarding accounting performance and market performance.

The presence of women on the board of directors has been a keen issue in governance, though the number has increased over the years especially in financial institutions but the expectation in terms of the impact on performance for firms with considerable number of women on the board and a mix of different ethnic personality is still under debate. Higgs (2003) submits that the incorporation of women on board of directors is essential especially in organizations thathavelittle or no female representation.

In U.S, the law mandates public listed firms to have at least one director and advices increase in female board membership. Experiences from Spain, France, Norway, Iceland and several 
developed nations indicate that women should comprise of at least $40 \%$ of board members especially in listed firms.

Post and Byron (2015) submission on the relationship between female board representation and performance showed positive to accounting measurements but negative to market performance measurements.

A Columbia study submits that women on boards helped companies to conclude merger and acquisition deals at a cost reduction of $15.4 \%$. In the same vein, Mckinsey's (n.d) study indicates that companies that allow for gender diversity within the workplace are $15 \%$ more likely to experience higher financial returns measured by EBIT. Country studies abroad show mixed views. Issa, Elfeky and Ullah (2019) study in Kuwait showed a positive association between board diversity and firm value. Croatian study by Kramaric and Toni-Milun (2016) showed women acting at top management position to positively influence Croatian firm's value. Agyemang-Mintah and Schadewitz (2017) UK study showed a positive relationship with firm value. Syamsudin, Setiany and Erna (2017) Indonesia study showed a positive effect on firm value. Anh and Khanh (2017) international study showed a negative effect on firm market value.

Female presence on the board should not just be a form of tokenism rather to exerciseexpertisethat adds value to the organization.

\section{Education Qualification}

The educational qualification of directors or board members serve as an important factor in decision perception of board members. Empirical research linking educational qualification of board members to firm value is very limited. Existing findings are inconclusive, this still attracts the search light of researchers and professionals. A U.S study by Nguyen et al. (2015) shows that board member education creates shareholder's wealth in the US banking sector. Ujunwa (2012) submits a positive and significant relationship between directors with $\mathrm{PhD}$ and financial performance. Yermack (2006) reported that share price reacts to director's professional qualification most importantly in the area of accounting and finance. Haniffa and Cooke (2002) found a positive relationship between accounting education of board members and disclosure of information. Gande and Kalpathy (2017) posits that the presence of a CEO with an MBA from 20 business school ranking positively improves a bank's buy and hold returns. Fernandes et al. (2017b) emphasized that directors' qualifications may affect banks' performance, and if the level of directors' qualifications are higher, they will be capable of making better corporate decisions. Hopt (2013) argued that 'qualification' or 'experience' of bank board members is, in fact, more important than their 'independence', representing a variable much investigated by many authors. Empirical bridge between board's member qualification and firm value is scanty and inconclusive in results submissions. The study enlarges literature by linking the variables.

\section{Independent directors}

Board independence assures the degree at which board decisions are without bias and further assures the credibility of financial reports. The composition of board of directors which includes executive and non-executive directors is involved in the management and policy making, strategic planning for the company. Executive directors tend to own shares in the firms, engineering personal interest in the company's public goodwill. This implies that directors can engage creative accounting in window dressing financial reports and presenting an untrue 
pictorial firm value. Non-executive directors being external personalities are not involved in the day to day running of the business but just engaged in policy making and planning exercise. The non-executivedirectorsact in the interest of the stakeholders with great objectivity. The nonexecutive directors act as checks to possible excesses from the executive directors in maintaining truism in firm public representation and settling agency problem or conflict of interest between management and stockholders or other stakeholders.

\section{Firm Value}

A firm's value, also known as Firm Value (FV) is an economic concept that reflects the value of a business. It is the value that a business is worthy of at a particular date. Theoretically, it is an amount that one needs to pay to buy/take over a business entity.

Diversity is seen to create creativity, innovativeness and quality decision process at board level. Board of directors being influential players in corporate entities and acting agents for the shareholders have the duty of maximizing shareholders'wealth. The upper echelon theory proposed by Hambrick and Mason (1984) best explains board diversity as it affects firm value. This is achieved through the competitive behavioral nature of the diverse board members which will enhance firm value. Firm value in the study is measured as the average market price of shares multiply by the share volume outstanding.

\section{Figure 1: Conceptual Framework}

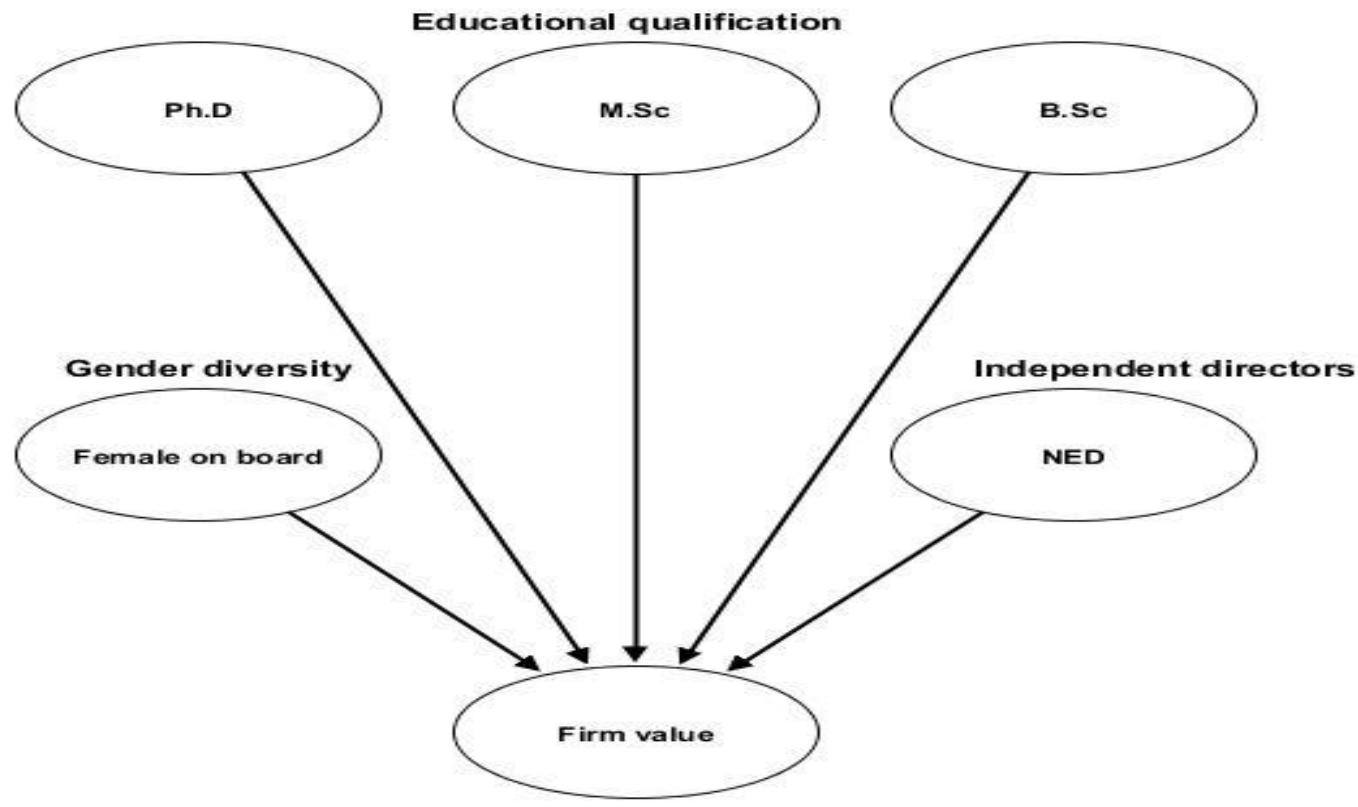

Source: Adopted and modeified from (Alomari 2016; Syamsudin, Setiany \& Sajidah 2017) 


\section{Methodology}

The expost facto research design was adopted engaging panel data sourced from the fourteen (14) listed deposit money banks (DMBs) in Nigeria. The banks' audited financial statements were sourced fromNSE.The study covered a ten (10) year period from 2010-2019.

\section{Model specification}

$\mathrm{FV}=\alpha_{\mathrm{o}}+\alpha_{1} \mathrm{GEND}+\alpha_{2} \mathrm{EDUQ}+\alpha_{3} \mathrm{IND}+\mathrm{e}$

The model is enlarged thus:

MPS $=\beta_{0}+\beta_{1} \mathrm{M}+\beta_{2} \mathrm{~F}+\beta_{3} \mathrm{PhD}+\beta_{4} \mathrm{MSc}+\beta_{5} \mathrm{BSc}+\beta_{6} \mathrm{ED}+\beta_{7} \mathrm{NED}$

Where $\beta_{1}$ and $\beta_{2}$ represents $\alpha_{1}$

$\beta_{3}, \beta_{4}$ and $\beta_{5}$ represents $\alpha_{2}$

$\beta_{6}$ and $\beta_{7}$ represents $\alpha_{3}$

\begin{tabular}{|l|l|l|l|}
\hline Variable & Denote & Measurement & $\begin{array}{l}\text { Priori } \\
\text { expectation }\end{array}$ \\
\hline Firm value & MPS & $\begin{array}{l}\text { Measured as average market } \\
\text { price per share/ Share outstanding }\end{array}$ & + \\
\hline Gender & GEND & $\begin{array}{l}\text { Ratio of female on board to total } \\
\text { board members }\end{array}$ & + \\
\hline $\begin{array}{l}\text { Educational } \\
\text { qualification }\end{array}$ & EDUQ & $\begin{array}{l}\text { Ratio of educational qualification } \\
\text { of board members showing BSc, } \\
\text { MSc and PhD }\end{array}$ & \pm \\
\hline Independent directors & IND & $\begin{array}{l}\text { Ratio of executive directors } \\
\text { (ED)and non-executive directors } \\
\text { (NED) to total directors }\end{array}$ & + \\
\hline
\end{tabular}

\section{Data analysis}

Construct Coefficient of determination $\left(\mathrm{R}^{2}\right) \quad$ Adjusted $\mathrm{R}^{2}$
FV
0.3497
0.3058

The adjusted $\mathrm{R}^{2} 0.3058$ indicates a $30.58 \%$ variation in the dependent variable based on the independent variables captured in the study. This explains the predictors have $30.58 \%$ influence on the fluctuation of fair value leaving $69.42 \%$ to other factors not captured in this study. 
Effect Overview

\begin{tabular}{|c|c|c|c|c|}
\hline Effect & Beta & Indirect effects & Total effect & Cohen's $\mathrm{f}^{2}$ \\
\hline Female -> FV & 0.2154 & & 0.2154 & 0.1549 \\
\hline $\mathrm{BSc} \rightarrow \mathrm{FV}$ & -21489.7979 & & -21489.7979 & 0.1674 \\
\hline $\mathrm{MSc}->\mathrm{FV}$ & -25872.4529 & & -25872.4529 & 0.1674 \\
\hline $\mathrm{PhD} \rightarrow \mathrm{FV}$ & -18658.8035 & & -18658.8035 & 0.1674 \\
\hline NED $->$ FV & 0.0324 & & 0.0324 & 0.1607 \\
\hline
\end{tabular}

The regression result revealed the individual effect of the predictors on the dependent variable(firm value). The beta coefficient for gender diversity measured as female on board show a coefficient value 0.2154 which indicates a positive effect of female on board on firm value of financial institutions. The educational qualification measured as Ph.D., M.Sc., and B.Sc. degrees obtained by the board members show $-18658.8035,-25872.4529$ and -21489.7979 negative values respectively. Independent directors measured as non-executive directors shows 0.0324 positive value. Effect size is a measure of the strength of the relationship between variables. TheCohen's $f^{2}$ measures the effect size of the sequential linear regression. In the rule of thumb, values of $0.10,0.25$, and 0.40 represent small, medium, and large effect sizes, respectively. The present results show the values increasing from $f^{2} 0.1549$ to 0.1674 for all the predictors on firm value. This explains that effect size of board diversity measured as gender diversity, educational qualification and independent directors is medium on firm value of listed financial institutions in Nigeria.

\section{Figure 2: Graphical representation of the regression Result}

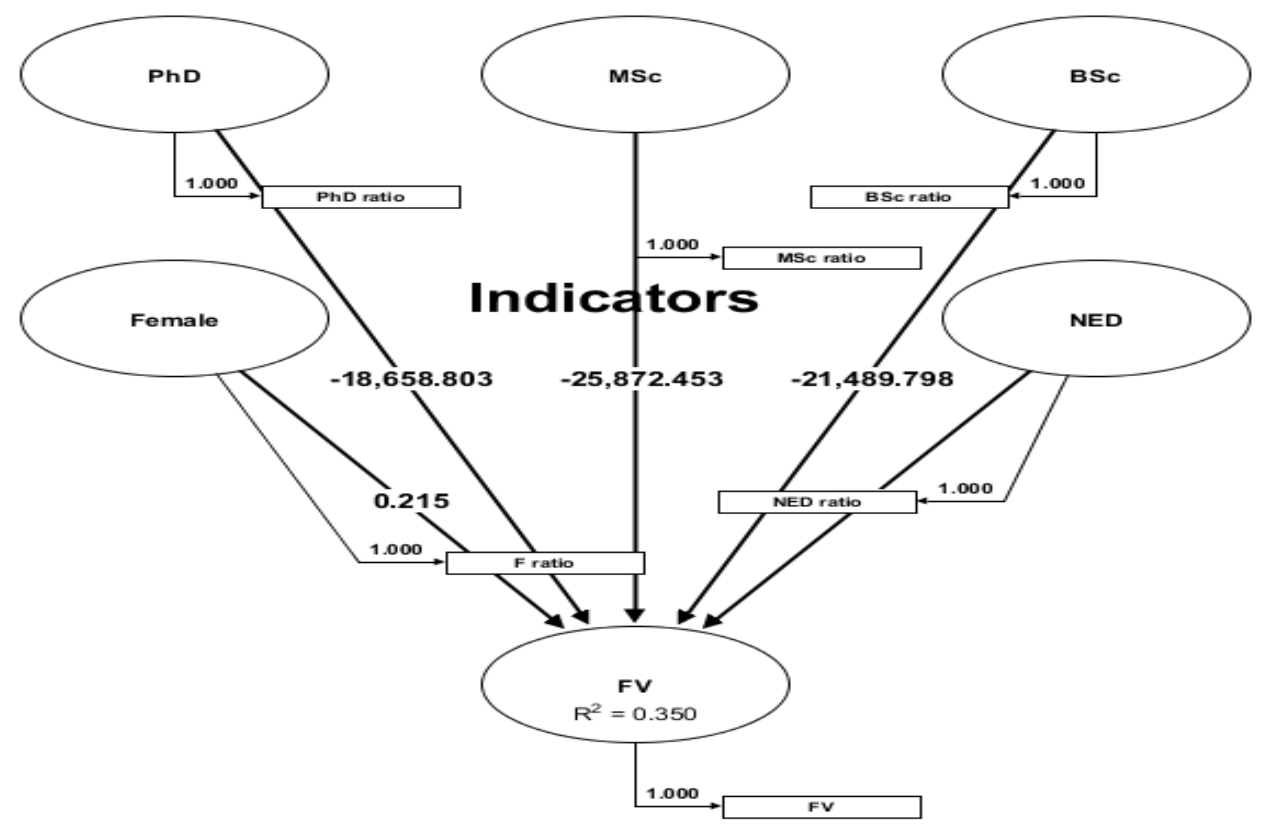

Source: Author's model result (Adanco 2.1.1) 


\section{Findings of the Study}

The study examined the board diversity of financial institutions in Nigeria and its effect on firm value with particular reference to deposit money banks. The predictive variables used in the study showed a combined influence on firm value of deposit money banks in Nigeria. The direct effect of the individual predictors showed a negative and positive effect. Gender diversity which focused on the number of females on the board of directors showed a positive effect on firm value.This is in agreement with Issa, Elfeky and Ulla (2019)findings that showed a significant relationship between women on board and firm performance. Anh and Khanh (2017) submission contradicts the above findings as it revealed a negative relationship. Educational qualification of board members measured as the number Ph.D, M.Sc and B.Sc degree holders showed a negative effect on firm value of financial institutions. This finding supports Alomari (2016) submission. Independent directors measured as the number of non-executive directors showed a positive effect on firm value. This explains that a substantial number of independent directors sitting on BOD of deposit money banks has the capacity to improve firm value of banks.

\section{Conclusion/Recommendation}

Board diversity is a debated issue in corporate governance as much as it considers the characteristics of board members and how it affects firm performance. Female representation in BOD has conflicting submissions in previous literatures. Nonetheless, it is viewed that women on board has a positive influence on the efficiency of company's board strategic policies that enhances performance. Independence of directors depicts freedom from influence allowing judgements and opinions that are in the best interest of the company without bias and preconceived ideas. This is achievable if the board directors include a substantive number of nonexecutive directors who are not subject to the management influence. The educational qualification of board member has not shown a possible influence on the enhancement. Thus, the study recommends that deposit money banks and other financial institutions should have a good quota of female directors on the BOD and furthermore, substantive non-executive directors should be represented in the BOD to allow unbiased decisions and quality reports. 


\section{References}

Agyemang-Mintah, P. \& Schadewitz, H. (2017). Gender Diversity and Firm Value: Evidence from UK Financial Institutions. International Journal of Accounting \& Information Management, 26(2), 2-32

Alomari, A.M. (2016). The Impact of Board of Directors and CEO Educational Qualifications and Experience on Performance: A Field Study on Manufacturing Companies Listed on the Amman Stock Exchange (master's thesis), Yarmouk university.

Anh, V.T.T \& Khanh, B.P.N (2017). Impact of Board Gender Diversity on Firm Value: International Evidence. Journal of Economics and Development, 19(1),65-76.

Campbell, K., \& Minguez-Vera, A. (2008). Gender Diversity in the Boardroom and Firm Financial Performance.Journal of Business Ethnics, 83, 435-451.

Cox, T., \& Blake, S. (1991). Managing Cultural Diversity: Implications for Organizational Competitiveness. Academy of Management Executive, 5(3), 45-55.

Erhardt, N., Werbel, J., \&Shrader, C. (2003). Board of Directors Diversity and Firm Financial Performance, Corporate Governance.An International Review, 102-111.

Fernandes, C., Jorge Farinha, J., Vitorino Martins, F. \&Mateus, C. 2017b. Supervisory boards, financial crisis and bank performance: do board characteristics matter? Journal of banking regulation, $18,310-337$.

Hambrick, D. C., \& Mason, P. A. (1984). Upper Echelons: The organizations as a reflection of its top managers. Academy of Management Review, 9(2), 193 - 206.

Haniffa, R. M., \& Cooke, T. E. (2002). Culture, Corporate Governance and Disclosure in Malaysian Corporations. Abacus, 38(3), 317-349.

Higgs, D. (2003). Review of the role and effectiveness of non-executive directors, Department of Trade and Industry, UK, http://www.berr.gov.uk/files/file23012.pdf

Hillman, A., Cannella, A. J., \& Harris, I. (2002). Women and Racial Minorities in the Boardroom: how do directors differ.Journal of Management, 747-763.

Hopt, K.J. 2013. Better governance of financial institutions. In ECGI Working Paper Series in Law. European Corporate Governance Institute.

Issaa, A., Elfeky, M.I. \& Ullah, I. (2019). The Impact of Board Gender Diversity on Firm Value: Evidence from Kuwait. International journal of applied science and research, 2(1), 1-21.

Kramaric, T.P., Milun, T. \& Pavic, I. (2016). Does gender diversity in the boardroom influence tobin's q of Croatian listed firms. International Journal of Economic Sciences, V(3), 50-65.

Nguyen, D., Duy, L., Hagendorff, J., Eshraghi, A. (2015). Which executive characteristics create value in banking? Evidence from appointment announcements. Corporate Governance. AnInternational Review, 23, 112-128 
Post, C., \& Byron, K. (2015). Women on boards and firm financial performance: a metaanalysis. Academy of Management Journal, 58(5), 1546-1571.

Syamsudin, S., Setiany, E. \& Sajidah, S.(2017). Gender Diversity and Firm Value: A Study On Boards of Public Manufacturing Firms in Indonesia. Problems and Perspectives in Management,5(3), 276-284.

Ujunwa, A. (2012). Board characteristics and financial performance of Nigerian quoted firms. Corporate Governance, 12(5), 656-674.

Yermack, D. (2006). Board Members and Company Value. Financial Markets Portfoli Management, 20(1), 33-47. 